\title{
Wheat Yield Response to Foliar Fungicide Application against Leaf Rust Caused by Puccinia triticina
}

\author{
Krishna Dev Joshi ${ }^{1}$, Ghulam Ullah ${ }^{1}$, Attiq Ur Rehman ${ }^{1}$, Muhammad Makky Javaid ${ }^{2}$, Javed Ahmad $^{2}$, Makhdoom \\ Hussain $^{2}$, Angela Pacheco ${ }^{3}$, Ibni Amin Khalil ${ }^{4}$ and Amanullah Baloch ${ }^{1}$ \\ 1. International Maize and Wheat Improvement Center (CIMMYT), Islamabad 44000, Pakistan \\ 2. Wheat Research Institute, Faisalabad 38000, Pakistan \\ 3. International Maize and Wheat Improvement Center (CIMMYT), Texcoco, Edo. de México, CP 56130, Mexico \\ 4. Cereal Crops Research Institute, Nowshera 24100, Pakistan
}

\begin{abstract}
A study was conducted on reducing the yield loss of wheat due to leaf rust caused by Puccinia triticina with foliar application of fungicides during the 2014-2015 and 2015-2016 growing seasons at the Wheat Research Institute in Faisalabad, Pakistan. Three fungicides: Folicur (tebuconazole) at $300 \mathrm{~mL} / \mathrm{ha}$, Nativo (tebuconazole + trifloxystrobin) at $300 \mathrm{~g} / \mathrm{ha}$ and Tilt (propiconazole) at $500 \mathrm{~mL} / \mathrm{ha}$ were applied single or two times to Morocco and Sehar-06 wheat varieties used in the trial. The trial plots were first sprayed at the Zadok's scale (ZS) 3 stage and second sprayed between ZS 4.3 and 5.4 stages. The greenness of the trial crop was measured using GreenSeeker. Foliar application of fungicides significantly reduced the loss of grain yield and 1,000-grain weight (TGW) of wheat due to leaf rust in comparison to the control without fungicides application. Of the three fungicides, two times spray of Nativo reduced the grain yield loss of leaf rust susceptible mega wheat variety Sehar- 06 by $45 \%-56 \%$ and the loss of TGW by $42 \%$, also giving the highest marginal return in the trial. Single application of Nativo was equally effective as two times spray of Folicur in reducing the loss of wheat grain yield. Two times spray of Folicur was found to be the second choice of fungicide for reducing the yield loss of wheat. The research identified suitable fungicides for reducing the yield loss of wheat due to leaf rust and also generated important scientific knowledge required to manage a sudden outbreak of leaf rust to ensure food security.
\end{abstract}

Key words: Wheat variety, leaf rust, yield loss, yield response, foliar spray of fungicide, resistance breeding.

\section{Introduction}

Wheat rust is a group of deadly, constantly changing, most destructive fungal pathogens that pose a serious threat to wheat crops worldwide. Three types of rust, i.e., leaf, stem and stripe rusts, are the most economically damaging diseases of wheat. All three can cause heavy losses when epidemics occur, but stem and stripe rusts are the most harmful, causing losses ranging from $60 \%$ to $100 \%[1,2]$. Under epidemic conditions, wheat losses due to rust diseases have caused famines and had a negative impact on national economies $[1,2]$.

Leaf or brown rust caused by Puccinia triticina is

Corresponding author: Krishna Dev Joshi, Ph.D., research fields: plant breeding and crop improvement. one of the most destructive and devastating diseases, due to the timing of its appearance in the plant growth cycle and the nature of its attack. Leaf rust poses a particular challenge, because it occurs frequently and thrives in prolonged growing seasons of the type that is prevalent in the wheat growing areas of the world. It has occurred in epidemic form several times in Pakistan [3] and the resulting yield losses were reported to be $40 \%$ to $50 \%$ [4]. However, the extent of losses is in part dependent upon the level of susceptibility or resistance of wheat varieties grown by the farmers [5].

Due to the heavy infection caused by rusts, the growth and yield parameter of wheat plants are adversely affected [6]. In Pakistan, leaf rust typically develops rapidly during the month of March when 
temperatures range between $10{ }^{\circ} \mathrm{C}$ and $30{ }^{\circ} \mathrm{C}$ accompanying with high humidity. During this period, fungal growth coincides with anthesis to grain development (Zadok's scale 6-8) of wheat [7]. More recently, due to change in weather, the disease has started appearing towards the end of January. Losses in grain yield are primarily due to reduced flower set and grain shriveling. In highly susceptible wheat varieties, the crop can be killed by early epidemics [8]. Fungicides offer a practical, rapid-response solution to combat rust outbreaks, and fungicide management of rust also provides adequate time for experts to make full assessment of the races and multiply new resistant varieties to quickly replace susceptible varieties [8].

Various fungicides are used to reduce the yield loss of wheat due to rust, but with varying efficacies [9]. A single spray of various fungicides at the first appearance of disease symptoms was reported to be effective in reducing the loss of wheat yield due to stripe rust up to $38 \%$ and the loss in 1,000-grain weight (TGW) of up to $24 \%$ was achieved in the same experiment by spraying fungicides twice in Central Asia [10].

It is well established that resistance breeding, fast tracking variety testing, release and deployment of new high yielding varieties with durable resistance to rust with diverse genetic background will always remain the core strategy for managing wheat rusts $[3$, 8]. However, the use of fungicides should also be one of the important elements of overall rust management strategies. Background researches indicate a lack of recent empirical data in Pakistan on the use of most efficacious fungicides, number of sprays and the returns on cost of using fungicides to reduce the yield loss of wheat due to leaf rust. The study was conducted to assess to which extent the yield loss of wheat caused by leaf rust might be reduced through the use of the most effective fungicides available in Pakistan.

\section{Materials and Methods}

The study was conducted during the 2014-2015 and
2015-2016 wheat-growing seasons at the Wheat Research Institute in Faisalabad, the hotspot of leaf rust in Pakistan. The experiment was laid down as a split-split plot design with two replications. The size of an individual plot was $8.1 \mathrm{~m}^{2}$.

\subsection{Wheat Varieties and Fungicides Used in the Experiment}

Two wheat varieties-Morocco, a universal susceptible check for wheat rust and Sehar-06, a moderately susceptible variety to leaf rust that is very widely grown in Pakistan, were used in the study, while AAS-11 was also included as a resistant check. The trial was planted on November 27 in both growing seasons. Three fungicides-Folicur (tebuconazole), Nativo (tebuconazole + trifloxystrobin) and Tilt (propiconazole) were respectively sprayed one or two times, while the wheat without fungicide sprays was as the control plot in the experiment. Two sprays of each fungicide were administered during both the seasons. The first occurrence of leaf rust was recorded in the last week of January in both 2015 and 2016. Foliar spray of fungicides was aligned with wheat growth stages and Zadok's scale, which is a scale of wheat development recognized internationally for research, advisory work and farm practice, particularly to time the application of chemicals and fertilizers [11]. Pre-rust emergence application of fungicides mostly coincided with Zadok's scale 3 (stem elongation and jointing), while the second spray was done between booting and flowering time (Zadok's scale 4.3 and 5.4). The quantity of fungicides used per spray was $300 \mathrm{~mL} /$ ha for Folicur, $300 \mathrm{~g} /$ ha for Nativo and $500 \mathrm{~mL} /$ ha for Tilt.

\subsection{Data Collection}

Incidence of leaf rust in the trial was measured. In addition, the vegetation index of the trial was measured using a handheld active optical sensor known as a "GreenSeeker" (Trimble Industries, Inc., U.S.A.), to add to the precision of the study. 
Vegetation index was measured on March 30, both in 2015 and 2016, which coincided with grain filling stage. Earlier studies have reported the relationships between spectral reflectance and level of rust infection [12-15]. Normalized difference vegetation index $(N D V I)$ was reported to be useful in predicting photosynthetic activity, plant health and level of stresses, including plant diseases. $N D V I$ is sensitive to the presence of vegetation, which absorbs radiant energy in the red band through chlorophyll, but reflects energy in the near infrared band [16], it is calculated by Eq. (1):

$$
N D V I=\frac{N I R-V I S r}{N I R+V I S r}
$$

where, $N I R=$ near-infrared radiation; $V I S r=$ visible red spectrum.

$N D V I$ values range from 0.00 to 0.99 . The greater the difference between the reflected light signals, the denser and more vigorous the plant, and vice versa.

The crop was harvested in the last week of April during both trial seasons. At maturity, individual plots were harvested disregarding two border rows on both sides of the plot. Grain yield and TGW were recorded for each of the treatments in the study.

\subsection{Data Analysis}

The experimental design established in the field was a split-split-plot. However, for the data analysis, since the experiment involved many factors with different levels of complexity, an unbalanced factorial analysis was deployed. The effects of all possible combinations were investigated using the following model, as Eq. (2):

$y=\mu+$ possible interactions of $\mathrm{V} \times \mathrm{F} \times \mathrm{S} \times \mathrm{Y}+\varepsilon$ (2) where, $\mathrm{V}$ : variety; $\mathrm{F}$ : fungicide; $\mathrm{S}$ : spray; $\mathrm{Y}$ : year; $y$ : the vector of observations including the replications; $\mu$ : the overall mean; $\varepsilon$ : the random error component.

Adjusting this model (ANOVA) allowed for an interpretation and statistical justification to determine the existence of significant characteristics of varieties, fungicide types and number of spray applications in any given year. The approach enabled a grouping of the elements according to their differences within each factor, using the least significant difference (LSD), which creates confidence intervals for all paired differences between means of factor levels, while controlling the individual error rate according to a level of significance of $5 \%$. Data were analyzed using Genstat software.

Potential reduction of grain yield loss (in the absence of foliar spray of fungicides) was calculated as yield difference between fungicides sprayed and control treatment for each variety expressed in percentage of the sprayed plots [10], as Eq. (3):

$$
\text { Reduction }(\%)=\frac{Y s p-Y n s p}{Y s p} \times 100
$$

where, $Y s p$ and Ynsp indicate grain yield under sprayed and non-sprayed conditions, respectively.

AAS-11 a leaf rust resistant variety was disregarded from all analysis.

Marginal return was obtained by subtracting gross return of unsprayed control treatment from the gross return of each of the fungicide treatments (dollars/ha). Total variable cost in the experiment was only the cost of fungicide application, including the cost of fungicide as well as cost of spraying it (dollars/ha).

\section{Results and Discussion}

\subsection{Grain Yield}

Foliar application of fungicides significantly reduced the wheat grain yield loss due to leaf rust during 2014-2015 (Table 1). This resulted from the interaction effect of fungicides, times of fungicide application and wheat varieties. In the case of the Morocco variety, single application of Nativo and two applications of Folicur and Nativo produced significantly higher grain yield over single spray of Tilt. In case of Sehar-06, two sprays of Nativo produced the highest grain yield (2.46 ton/ha), which was significantly superior to the rest of the treatments. 
Similarly, a single application of Nativo nearly had the same effect as two of Folicur in increasing the grain yield of wheat, this difference was not statistically significant (Table 1). However, there was no difference between unsprayed control and foliar application of both single and double applications of Tilt, as well as single spray of Folicur and Nativo. Tilt has a systemic mode of action with protective and curative function with more of fungal growth inhibiting rather than fungicidal properties [17]. Conversely, Nativo contains two active ingredientstebuconazole and trifloxystrobin. Tebuconazole interferes in process of building the structure of fungal cell wall, ultimately inhibiting the reproduction and further growth of fungi, while trifloxystrobin interferes with respiration in plant pathogenic fungi. The reasons for the effectiveness of Nativo are also due to its built in anti-resistance management, beneficial effects on plant health, yield and quality [18].

There was no interaction between any of the three factors for grain yield in the trial. In the 2015-2016 season, there was no significant difference between three fungicides either with single or two foliar applications in reducing the grain yield of wheat. No significant interaction between any of these factors could be found during the second year of trial (Table 2).

Potential yield reduction in the absence of foliar spray of fungicides was calculated. This ranged from $1 \%$ to $45.5 \%$ for Sehar- 06 , and two spray applications of Nativo between ZS 4.3 and 5.4 resulted in the highest yield reduction, followed by two spray applications of Folicur during 2014-2015. The range was much higher for Morocco which treated with two spray applications of Folicur, followed by two sprays of Nativo.

Overall, grain yield levels were very low in these research trials. The average grain yield of Sehar-06 was only 1.15 ton/ha, while average grain yield of the same variety was reported to be 3.64 ton/ha during the same period from on-farm trials where there was no disease [19]. Such a low grain yield of Sehar-06 in the same season from an on-station trial was due to extreme suppression of its yield potential by leaf rust.

The trial plot was surrounded by a number of rust screening nurseries that created immense disease pressure. Leaf rust incidence ranged between $30 \%$ to $100 \%$ during first year and $50 \%$ to $100 \%$ during the second year of the study. The trial was done at Wheat Research Institute, Faisalabad, which is a known hotspot of leaf rust in Pakistan due to a buildup of rust inoculums, as wheat rust nurseries, including leaf rust and trap nurseries, are conducted in this location since the early 1970s. Heavy disease pressure can knock down or severely suppress the yield potential of resistant wheat varieties, while the impact of such disease inoculum on susceptible varieties can be enormous. Yield reduction from $12 \%$ to $28 \%$ due to leaf rust on resistant wheat varieties was reported as a result of a direct relationship between the density of rust inoculum and the amount of necrosis on varieties that are resistant but not immune [20]. The findings in this paper also agree with these results; the average grain yield of AAS-11, a leaf rust resistant wheat variety in the same trial was 2.2 ton/ha over a two-year period, contrary to its yield potential of 6 ton/ha under normal rust free conditions.

The trial clearly demonstrated a difference in yield increase with the foliar application of appropriate fungicides. The response of moderately susceptible variety Sehar-06 to fungicide application resulted in nearly $84 \%$ increase in grain yield even at the hot spot of leaf rust. Low vegetation index due to exceptionally high rust incidence in the trial crop even with fungicide application also led to low grain yield. The research findings indicate that it is possible to harvest a reasonable grain yield from slightly-to-moderately susceptible wheat varieties even where rust inoculum build-up is as extreme as demonstrated in this research. However, this may not be feasible with highly susceptible varieties, like Morocco. 
Table 1 Reduction in the loss of grain yield and 1,000-grain weight (TGW) of wheat treated with three fungicides foliar spray against leaf rust in Pakistan in 2014-2015.

\begin{tabular}{|c|c|c|c|c|c|c|c|c|}
\hline Treatment and variety & $\begin{array}{l}\text { Disease } \\
\text { incidence (\%) }\end{array}$ & $\begin{array}{l}\text { Vegetation } \\
\text { index }(N D V I) \\
\end{array}$ & $\begin{array}{l}\text { Grain yield } \\
\text { (ton/ha) }\end{array}$ & TGW (g) & $\begin{array}{l}\text { Reduction (\%) } \\
\text { of yield loss }\end{array}$ & $\begin{array}{l}\text { Reduction (\%) of } \\
\text { TGW loss }\end{array}$ & $\begin{array}{l}\text { Gross revenue } \\
(\$)\end{array}$ & $\begin{array}{l}\text { Marginal return over } \\
\text { unsprayed control (\$) }\end{array}$ \\
\hline \multicolumn{9}{|l|}{ Morocco } \\
\hline Control & 100 & 0.35 & 0.37 & 19.65 & & & & \\
\hline Single spray Folicur & 65 & 0.49 & 0.53 & 24.68 & 30.2 & 20.4 & 178.6 & 53.9 \\
\hline Two sprays Folicur & 50 & 0.57 & 0.82 & 32.08 & 54.9 & 38.7 & 276.3 & 151.7 \\
\hline Single spray Nativo & 70 & 0.55 & 0.58 & 28.45 & 36.2 & 30.9 & 195.5 & 70.8 \\
\hline Two sprays Nativo & 25 & 0.59 & 0.69 & 33.63 & 46.4 & 41.6 & 232.5 & 107.8 \\
\hline Single spray Tilt & 90 & 0.40 & 0.49 & 22.83 & 24.5 & 13.9 & 165.1 & 40.4 \\
\hline Two sprays Tilt & 70 & 0.59 & 0.64 & 30.78 & 42.2 & 36.2 & 215.7 & 91.0 \\
\hline \multicolumn{9}{|l|}{ Sehar-06 } \\
\hline Control & 100 & 0.38 & 1.34 & 23.08 & & & & \\
\hline Single spray Folicur & 100 & 0.50 & 1.35 & 30.05 & 0.7 & 23.2 & 454.9 & 3.4 \\
\hline Two sprays Folicur & 55 & 0.51 & 1.69 & 36.95 & 20.7 & 37.5 & 569.5 & 118.0 \\
\hline Single spray Nativo & 100 & 0.55 & 1.38 & 32.13 & 2.9 & 28.2 & 465.1 & 13.5 \\
\hline Two sprays Nativo & 30 & 0.58 & 2.46 & 38.63 & 45.5 & 40.3 & 829.0 & 377.4 \\
\hline Single spray Tilt & 100 & 0.47 & 1.33 & 26.78 & -0.8 & 13.8 & 448.0 & -3.4 \\
\hline Two sprays Tilt & 80 & 0.55 & 1.35 & 32.28 & 0.7 & 28.5 & 454.9 & 3.4 \\
\hline \multicolumn{9}{|l|}{ LSD } \\
\hline Variety (V) & & 0.03 & $0.29 * *$ & $1.02 * *$ & & & & \\
\hline Fungicide $(\mathrm{F})$ & & $0.04 * *$ & 0.38 & $1.35 * *$ & & & & \\
\hline Spray (S) & & $0.03 * *$ & $0.31 *$ & $1.10 * *$ & & & & \\
\hline $\mathrm{F} \times \mathrm{S}$ & & $0.04 *$ & 0.38 & 1.35 & & & & \\
\hline $\mathrm{CV}$ & & 7.87 & 32.9 & 4.26 & & & & \\
\hline
\end{tabular}

$N D V I=$ normalized difference vegetation index; LSD $=$ least significant difference; $\mathrm{CV}=$ coefficient of variation; $*$ significant at $P \leq 0.05, * *$ significant at $P \leq 0.01$ and $* * *$ significant at $P \leq 0.001$. 
Table 2 Reduction in the loss of grain yield and 1,000-grain weight (TGW) of wheat treated with three fungicides foliar spray against leaf rust in Pakistan in $2015-2016$.

\begin{tabular}{|c|c|c|c|c|c|c|c|c|}
\hline Treatment and variety & $\begin{array}{l}\text { Disease } \\
\text { incidence (\%) }\end{array}$ & $\begin{array}{l}\text { Vegetation } \\
\text { index }(N D V I)\end{array}$ & $\begin{array}{l}\text { Grain yield } \\
\text { (ton/ha) }\end{array}$ & TGW (g) & $\begin{array}{l}\text { Reduction (\%) } \\
\text { of yield loss }\end{array}$ & $\begin{array}{l}\text { Reduction (\%) } \\
\text { of TGW loss }\end{array}$ & $\begin{array}{l}\text { Gross revenue } \\
(\$)\end{array}$ & $\begin{array}{l}\text { Marginal return over } \\
\text { unsprayed control (\$) }\end{array}$ \\
\hline \multicolumn{9}{|l|}{ Morocco } \\
\hline Control & 100 & 0.51 & 0.40 & 21.85 & & & & \\
\hline Single spray Folicur & 80 & 0.53 & 0.52 & 20.50 & 23.10 & 2.90 & 175.20 & 21.44 \\
\hline Two sprays Folicur & 75 & 0.59 & 1.05 & 26.55 & 61.90 & 17.70 & 353.90 & 180.95 \\
\hline Single spray Nativo & 95 & 0.65 & 0.46 & 18.50 & 13.00 & 7.00 & 155.00 & 1.22 \\
\hline Two sprays Nativo & 65 & 0.52 & 0.64 & 23.75 & 37.50 & 8.00 & 215.70 & 42.78 \\
\hline Single spray Tilt & 100 & 0.57 & 0.53 & 23.20 & 24.50 & 5.80 & 178.60 & 28.31 \\
\hline Two sprays Tilt & 90 & 0.65 & 0.35 & 20.20 & -14.30 & -8.20 & 118.00 & -47.85 \\
\hline \multicolumn{9}{|l|}{ Sehar-06 } \\
\hline Control & 90 & 0.51 & 0.80 & 32.95 & 27.90 & 3.70 & & \\
\hline Single spray Folicur & 95 & 0.53 & 1.11 & 26.65 & 38.90 & 1.95 & 374.10 & 104.50 \\
\hline Two sprays Folicur & 50 & 0.59 & 1.31 & 24.90 & 46.70 & 2.05 & 441.50 & 67.40 \\
\hline Single spray Nativo & 85 & 0.52 & 1.50 & 25.00 & 56.00 & 1.80 & 505.50 & 131.43 \\
\hline Two sprays Nativo & 65 & 0.57 & 1.82 & 24.75 & 44.80 & -1.00 & 613.30 & 239.27 \\
\hline Single spray Tilt & 100 & 0.57 & 1.45 & 21.95 & 37.00 & 2.25 & 488.70 & 114.58 \\
\hline Two sprays Tilt & 90 & 0.60 & 1.27 & 25.20 & 27.90 & 3.70 & 428.00 & 53.92 \\
\hline \multicolumn{9}{|l|}{ LSD } \\
\hline Variety (V) & & $0.02 * *$ & $0.27 * *$ & 2.95 & & & & \\
\hline Fungicide $(\mathrm{F})$ & & $0.02 * *$ & 0.35 & 3.82 & & & & \\
\hline Spray (S) & & $0.03 * *$ & 0.35 & $3.82 * *$ & & & & \\
\hline $\mathrm{CV}$ & & 4.90 & 43.40 & 17.21 & & & & \\
\hline
\end{tabular}

$\overline{N D V I}=$ normalized difference vegetation index; LSD $=$ least significant difference; $\mathrm{CV}=$ coefficient of variation; $*$ significant at $\mathrm{P} \leq 0.05 ; * *$ significant at $P \leq 0.01$ and $* * *$ significant at $P \leq 0.001$. 


\subsection{TGW}

TGW of wheat varied greatly between unsprayed control and other treatments, and Morocco and Sehar-06 responded positively to the foliar application of fungicides. A reduction in TGW of a rust-infested crop mainly arises from shriveled grains, and ultimately reduces the yield and quality of wheat grains. Previous studies have indicated that seeds produced from a crop damaged by rust exhibit poor emergence and low vigor after germination [21]. The knowledge generated through this research indicates that all three fungicides were able to improve the TGW of wheat.

Overall, higher TGW was observed during the 2014-2015 season in comparison to the 2015-2016. The differences were highly significant for wheat variety, type of fungicides and times of spray applications during 2014-2015, while only times of fungicide application influenced TGW between treatments during 2015-2016. No significant interactions for TGW between any of the factors were observed in the trial. The reduction in loss of TGW with fungicides application ranged from $13.9 \%$ to $41.6 \%$ for Morocco and from $13.8 \%$ to $40.3 \%$ for Sehar-06. Nativo and Folicur reduced the loss of TGW more notably compared to Tilt. During 2015-2016, the reduction in TGW was much more variable and only a maximum of $11.7 \%$ reduction in the loss of TGW could be achieved with Morocco, while this was less than $5 \%$ for Sehar-06 (Table 2). The effect of variety, fungicide and times of fungicide applications at specific crop growth stages were significant for TGW.

TGW measure is probably the best indicator to estimate the effect of rust on wheat grain yield and quality. Additionally, it also provides a clear indication of the response of wheat varieties to the foliar application of fungicides. A noteworthy finding is that TGW of highly susceptible varieties, such as Morocco, is more severely affected than moderately susceptible varieties. The highest reduction of TGW in the trial was achieved in both instances with two sprays of Nativo, which was also statistically significant. This further strengthens the efficacy of Nativo in managing leaf rust.

\subsection{Relationship between Vegetation Index and Grain Yield}

Vegetation index reflects the plant health, crop vigor and the level of stress experienced by the plants. The NDVI value of 0.51 (2014-2015) and 0.56 (2015-2016) were low in the experiment, indicating that experimental crop was not healthy due to high rust incidence (Tables 1 and 2). It is clear that in about $50 \%$ of cases, grain yield recorded in the trial was higher than 1 ton/ha and that all of these points lie in the area with above average vegetation indices. The $N D V I$ values could explain about one third of the variation in average wheat grain yield $\left(r^{2}=0.337 ; P=\right.$ $<0.0021)$ in the trial.

\subsection{Fungicide Spray Application and Marginal Return}

For effective management of wheat rusts, fungicides would need to be applied between flag leaf initiation and ear emergence if the disease pressure reaches threshold level. Nativo proved to be effective when applied at growth between ZS 4.3 and 5.4 (close to booting) rather than a pre-rust emergence spray (close to stem elongation) as a protective measure. Similarly, application of Folicur between ZS 4.3 and 5.4 also increased wheat grain yields. In both cases, spray application administered close to booting was most effective in reducing wheat yield loss, because it appropriately coincided with early disease build up.

The research showed that Nativo is the best choice of fungicide for reducing wheat yield loss caused by leaf rust and thereby increasing the maximum grain yield and marginal return over the other two fungicides evaluated. In this research, $45 \%$ potential yield loss in the case of Sehar-06 was prevented with the use of fungicide, and this finding is in full agreement with previous studies that suggest up to $42 \%$ 
yield loss caused by fungal diseases can be prevented by applying foliar fungicides to winter wheat [21].

Overall, the marginal return from Morocco due to fungicide spray was low, except when two sprays of Folicur were applied. Two spray applications of Nativo gave the best marginal returns from Sehar-06 of all the three fungicides evaluated. Marginal returns ranged from $\$ 239.3 /$ ha to $\$ 377.4 /$ ha between two years (Tables 1 and 2). Two-year average net returns of \$52.09/ha was reported from a study involving one foliar spray of fungicide TebuStar ${ }^{\circledR} 3.6 \mathrm{~L} / \mathrm{ha}$ on four soft-red winter wheat cultivars [22]. Net returns of up to $\$ 239 /$ ha with foliar application of fungicides on winter wheat was also reported [23]. Another similar study indicated net returns being two times the total cost ( $\$ 2$ return on $\$ 1$ investment) in $85 \%$ of the treatments [24]. The findings in this study also agree with these results.

\section{Conclusions and Recommendation}

In this study, it can be concluded that it is possible to reduce the loss of grain yield and TGW of wheat due to leaf rust using fungicides. Nativo is the best choice of fungicide in the fight against leaf rust in Pakistan, as $45 \%-56 \%$ wheat yield loss of leaf rust susceptible mega wheat variety Sehar-06 could be reduced as demonstrated in this research. Two spray applications of Nativo also increased TGW and marginal return earned. Folicur can be used as a second choice fungicide. A pre-rust emergence foliar spray application at ZS 3 (close to stem elongation) as a protective measure was not enough in reducing yield loss of wheat, while a second application between ZS 4.3 and 5.4 (close to the booting stage) followed by the first application was more effective, as the latter appropriately coincided with early disease build up. In an epidemic situation, two spray applications would be more sensible for yield loss reduction, thereby increasing the total production per unit area. Appropriate fungicides identified and the new scientific knowledge revealed through this research offer great promise in reducing the yield loss of wheat due to leaf rust. Fungicides do not increase the yield potential of wheat varieties, but have the capacity to overcome the risk of losses resulting from rust and other fungal diseases, hence their use should form one of the important elements of an overall rust management strategy for ensuring food security.

\section{Acknowledgments}

The authors would like to thank Wheat Research Institute (WRI) in Faisalabad, Pakistan for efficiently implementing this study, Julie Mollins, International Maize and Wheat Improvement Center (CIMMYT), for editing support, and Bayer Crop Science and Syngenta Pakistan Offices for providing free samples of the fungicides used in the experiment. The authors are also thankful to the United States Agency for International Development (USAID) for providing financial support for this research through the Agricultural Innovation Program (AIP) for Pakistan.

\section{References}

[1] Agrios, G. 2005. Plant Pathology, 5th ed.. Boston, Mass: Elsevier Academic Press.

[2] Dubin, H. J., and Bernnan, J. P. 2009. "Combating Stem and Leaf Rust of Wheat: Historical Perspective, Impacts and Lessons Learned." International Food Policy Research Institute (IFPRI), United States of America. Accessed November, 2016. http://www.ifpri.org/publication/combating-stem-and-leaf -rust-wheat.

[3] Stuthman, D. D., Leonard, K. J., and Garvin, J. M. 2007. "Breeding Crops for Durable Resistance to Disease." Adv. in Agron. 95: 319-67.

[4] Ahmad, S., Afzal, M., Noorka, I. R., Iqbal, Z., Akhtar, N., Iftikhar, Y., and Kamran, M. 2010. "Prediction of Yield Losses in Wheat (Triticum aestivum L.) Caused by Yellow Rust in Relation to Epidemiological Factors in Faisalabad." Pak. J. Bot. 42 (1): 401-7.

[5] Beard, C., Jayasena, K., Thomas, G. J., and Loughman, R. 2007. "Managing Stripe Rust and Leaf Rust of Wheat." Farmnote No. 43/2005, Department of Agriculture, Government of West Australia. Accessed on July 7, 2013. http://www.nvtonline.com.au/wp-content/uploads/2013/0 3/Crop-Guide-WA-Farmnote-Managing-Stripe-Rust-andLeaf-Rust-of-Wheat.pdf. 
[6] Abebe, T., Dawit, W., and Woldeab, G. 2013. "Physiological Races and Virulence Diversity of Puccinia graminis pers. f. sp. tritici Eriks. \& E. Henn. on Wheat in Tigray Region of Ethiopia." Int. J. Plant Pathol. 2 (1): 1-7.

[7] Rattu, A. R., Ahmad, I., Singh, R. P., Fayyaz, M., Mirza, J. I., Khanzada, K. A., and Haque, M. I. 2010. "Resistance to Puccinia triticina in Some Pakistani Wheats." Pak. J. Bot. 42 (4): 2719-35.

[8] International Center for Agricultural Research in the Dry Areas (ICARDA). 2011. "Strategies to Reduce the Emerging Wheat Stripe Rust Disease." Presented at International Wheat Stripe Rust Symposium, April 18-20, 2011, Aleppo, Syria.

[9] Conner, R. L., and Kuzyk, A. D. 1988. "Effectiveness of Fungicides in Controlling Stripe Rust, Leaf Rust and Black Point in Soft White Spring Wheat." Can. J. Plant Pathol. 10: 321-6.

[10] Sharma, R. C., Nazari, K., Amanov, A., Ziyaev, Z., and Jalilov, A. U. 2016. "Reduction of Wheat Yield Losses Caused by Stripe Rust through Fungicide Management." J. Phytopathol. 164 (9): 671-7.

[11] Zadoks, J. C. 1972. "Methodology of Epidemiological Research." Ann. Rev. Phytopathol. 10: 253-76.

[12] Moshoua, D., Bravo, C., West, J., Wahlen, S., McCartney, A., and Ramona, H. 2004. "Automatic Detection of Yellow Rust in Wheat Using Reflectance Measurements and Neural Networks." Comput. Electron. Agric. 44 (3): $173-88$

[13] Huang, W. J., Lamb, D. W., Niu, Z., Zhang, Y. J., Liu, L. Y., and Wang, J. H. 2007. "Identification of Yellow Rust in Wheat Using in Situ Spectral Reflectance Measurements and Airborne Hyperspectral Imaging." Precis. Agric. 8 (4): 187-97.

[14] Devadas, R., Lamb, D. W., Simpfendorfer, S., and Backhouse, D. 2009. "Evaluating Ten Spectral Vegetation Indices for Identifying Rust Infection in Individual Wheat Leaves." Precis. Agric. 10: 459-70.

[15] Zhang, J. C., Huang, W. J., Li, J. Y., Yang, G. J., Luo, J. H., Gu, X. H., and Wang, J. H. 2011. "Development, Evaluation and Application of a Spectral Knowledge Base to Detect Yellow Rust in Winter Wheat." Precis.
Agric. 12 (5): 716-31.

[16] Verhulst, N., and Govaerts, B. 2010. The Normalized Difference Vegetation Index (NDVI) GreenSeeker ${ }^{T M}$ Handheld Sensor-Toward the Integrated Evaluation of Crop Management: Part A, Concepts and Case Studies. Mexico, DF: International Maize and Wheat Improvement Center (CIMMYT).

[17] Syngenta United States. 2017. “Tilt Fungicide.” Crop Protection, Syngenta US. Accessed on March 29, 2017. http://www.syngenta-us.com/fungicides/tilt.

[18] Crop Science, India. 2017. "Nativo®: Tebuconazole 50\% + Trifloxystrobin 25\% w/w WG (75 WG)." Accessed March 29, 2017. http://www.cropscience.bayer.in/Products-H/Brands/Crop -Protection/Fungicide-Nativo.aspx.

[19] Joshi, K. D., Rehman, A. U., Ullah, G., Nazir, M. F., Zahara, M., Akhtar, J., Baloch, A., Khokhar, J., Ellahi, E., Khan, M., Suleman, M., Khan, A., and Imtiaz, M. 2017. "Acceptance and Competitiveness of New Improved Wheat Varieties by Smallholder Farmers." J. Crop Improvement. doi: 10.1080/15427528.2017.1325808.

[20] Samborski, D. J., and Peturson, B. 1960. "Effect of Leaf Rust on the Yield of Resistant Wheats." Can. J. Plant Sci. 40: 620-3.

[21] Afzal, S. N., Haque, M. I., Ahmedani, M. S., Bashir, S., and Rattu, A. R. 2007. "Assessment of Yield Losses Caused by Puccinia striiformis Triggering Stripe Rust in the Most Common Wheat Varieties." Pak. J. Bot. 39 (6): 2127-34.

[22] Lopez, J. A., Rojas, K., and Swart, J. 2015. "The Economics of Foliar Application in Winter Wheat in Northeast Texas." Crop Prot. 67: 35-42.

[23] Wegulo, S. N., Stevens, J., Zwingman, M. V., and Baenziger, P. S. 2012. "Yield Response to Foliar Fungicide Application in Winter Wheat." In Fungicides for Plant and Animal Diseases, edited by Dhanasekaran, D., Thajuddin, N., and Paneerselvam, A. Rijeka, Croatia: InTech, 227-44.

[24] Wegulo, S. N., Zwingman, M. V., Breathnach, J. A., and Baenziger, P. S. 2011. "Economic Returns from Fungicide Application to Control Foliar Fungal Diseases in Winter Wheat." Crop Prot. 30 (6): 685-92. 